\title{
Downregulation of matrix metalloproteinase 14 by the antitumor miRNA, $m i R-150-5 p$, inhibits the aggressiveness of lung squamous cell carcinoma cells
}

\author{
TAKAYUKI SUETSUGU ${ }^{1 *}$, KEIICHI KOSHIZUKA ${ }^{2 *}$, NAOHIKO SEKI $^{2}$, KEIKO MIZUNO $^{1}$, \\ ATSUSHI OKATO ${ }^{2}$, TAKAYUKI ARAI ${ }^{2}$, SHUNSUKE MISONO ${ }^{1}$, AKIFUMI UCHIDA ${ }^{1}$, \\ TOMOHIRO KUMAMOTO ${ }^{1}$ and HIROMASA INOUE ${ }^{1}$ \\ ${ }^{1}$ Department of Pulmonary Medicine, Graduate School of Medical and Dental Sciences, \\ Kagoshima University, Kagoshima 890-8520; ${ }^{2}$ Department of Functional Genomics, \\ Chiba University Graduate School of Medicine, Chuo-ku, Chiba 260-8670, Japan
}

Received September 13, 2017; Accepted November 24, 2017

DOI: $10.3892 /$ ijo.2017.4232

\begin{abstract}
In the present study, in order to elucidate the aggressive nature of lung squamous cell carcinoma (LUSQ), we investigated the oncogenic RNA networks regulated by antitumor microRNAs (miRNAs or miRs) in LUSQ cells. The analysis of our original miRNA expression signatures of human cancers revealed that microRNA-150-5p (miR-150-5p) was downregulated in various types of cancer, indicating that $m i R-150-5 p$ acts as an antitumor miRNA by targeting several oncogenic genes. Thus, the aims of this study were to investigate the antitumor roles of $m i R-150-5 p$ in LUSQ cells and to identify oncogenes regulated by $m i R-150-5 p$ that are involved in the aggressive behavior of LUSQ. The downregulation of $m i R-150-5 p$ was validated in clinical samples of LUSQ and cell lines (SK-MES-1 and EBC-1). The ectopic overexpression of miR-150-5p significantly suppressed cancer cell aggressiveness. Comprehensive gene expression analyses revealed that $m i R-150-5 p$ regulated 9 genes in the LUSQ cells. Among these, matrix metalloproteinase 14 (MMP14) was found to be a direct target of $m i R-150-5 p$, as shown by luciferase reporter assay. The knockdown of MMP14 using siRNA against MMP14 (si-MMP14) significantly inhibited cancer cell migration and invasion. The overexpression of MMP14 was detected in clinical specimens of LUSQ by immunohistochemistry. On the whole, these findings suggest that the downregulation of
\end{abstract}

Correspondence to: Dr Naohiko Seki, Department of Functional Genomics, Chiba University Graduate School of Medicine, 1-8-1 Inohana, Chuo-ku, Chiba 260-8670, Japan

E-mail: naoseki@faculty.chiba-u.jp

*Contributed equally

Key words: microRNA, lung squamous cell carcinoma, $m i R-150-5 p$, matrix metalloproteinase 14 , antitumor $m i R-150-5 p$ and the overexpression of MMP14 may be deeply involved in the pathogenesis of LUSQ.

\section{Introduction}

The improvement of the treatment efficacy of lung cancer is an important issue worldwide. In 2012, 1.8 million individuals were diagnosed with lung cancer worldwide, resulting in the death of 1.6 million individuals (1). The majority of lung cancers (approximately 80\%) are classified as non-small cell lung cancer (NSCLC). NSCLC is subdivided into four histopathological subtypes as follows: adenocarcinoma (LUAD), squamous cell carcinoma (LUSQ), large cell carcinoma and neuroendocrine cancer (2). The overall survival rate of patients with NSCLC is poor as almost half of patients have metastatic disease at initial diagnosis (3). In patients with adenocarcinoma, the survival rates are markedly improved by treatment with epidermal growth factor receptor (EGFR)-tyrosine kinase inhibitors (TKIs), inhibitor of anaplastic lymphoma kinase (ALK) and immune check point drugs (4). By contrast, recent targeted molecular therapies have little benefit to the management of patients with LUSQ (5-7). Therefore, in order to improve the prognosis of patients with LUSQ, it is important to analyze the molecular mechanisms of metastatic pathways using the latest genomic approaches.

The human genome sequencing project has shown that a large proportion of non-coding RNAs (ncRNAs) are transcribed (8). The functions of ncRNAs are varied and they can act as effective regulatory molecules in a wide range of biological progresses (9). ncRNAs are categorized into two classes based on their molecular sizes: long ncRNAs (lncRNAs) and small ncRNAs (9). MicroRNAs (miRNAs or miRs) are members of the small ncRNA family. They are typically 19 to 23 nucleotides length, and they regulate the expression of protein-coding RNAs or non-coding RNAs (10). miRNAs possess unique properties, including the ability of a single miRNA species to regulate a vast number of protein-coding or ncRNAs in human cells (10). Thus, aberrantly expressed miRNAs can disrupt systematically regulated RNA networks 
in cancer cells. In fact, dysregulated miRNAs are deeply involved in the pathogenesis of human cancers (11).

To elucidate the aggressive nature of LUSQ, we previously identified miRNAs that play regulatory roles in this disease (12-16). For example, our previous studies have revealed that the clustered miRNAs, $m i R-1$ and $m i R-133 a$, markedly inhibit cancer cell aggressiveness by regulating actin binding protein CORO1C (12). All family members of $m i R-29$ (miR-29a, $m i R-29 b$ and $m i R-29 c)$ act as anti-metastatic miRNAs by targeting lysyl oxidase homolog 2 (LOXL2) $(13,14)$. The overexpression of LOXL2 has been observed in several types of cancer and the knockdown of LOXL2 interferes with cancer cell aggressiveness $(17,18)$. Moreover, $m i R-206$ has been shown to inhibit cancer cell malignancies by targeting two pivotal tyrosine kinase receptors, MET and EGFR, in LUSQ (16). These findings provide new knowledge into the novel molecular mechanisms underlying the pathogenesis of LUSQ.

The analysis of miRNA expression signatures of head and neck squamous cell carcinoma (HNSCC) by RNA sequencing revealed that $m i R-150-5 p$ was downregulated in cancer tissues (19). In addition, the downregulation of $m i R-150-5 p$ was detected in cancer signatures derived from prostate cancer and bladder cancer $(20,21)$. However, the functional significance of $m i R-150-5 p$ in LUSQ remains unknown. Thus, in this study, we focused on $m i R-150-5 p$ and investigated its functional significance and the regulatory RNA networks in LUSQ cells.

\section{Materials and methods}

Clinical samples and cell lines. In this study, a total of 33 LUSQs and 24 non-cancerous lung specimens apart from the tumors were obtained from patients who underwent lobectomy at Kagoshima University Hospital from 2010 to 2013. The clinicopathological data of the patients with LUSQ (33 LUSQs and 24 non-cancerous lung specimens) are summarized in Table I. Our study was approved by the Institutional Review Board for Clinical Research of Kagoshima University Hospital. Each patient provided written informed consent and approval prior to obtaining the samples.

Two human LUSQ cell lines (SK-MES-1and EBC-1) were used in this study as previously described $(15,16)$. The cell lines, SK-MES-1 and EBC-1, were obtained from the Japanese Cancer Research Resources Bank (JCRB) and the American Type Culture Collection (Manassas, VA, USA), respectively.

Mature miRNA and small interfering RNA transfection into LUSQ cells. The following RNA species were used in this study: mature miRNAs, Pre-miR ${ }^{\mathrm{TM}}$ miRNA Precursors (has-miR-150-5p, assay ID: PM 10070; Applied Biosystems, Foster City, CA, USA), negative control miRNA (Applied Biosystems, assay ID: AM 17111), small interfering RNA (Stealth Select RNAi siRNA, Invitrogen, si-MMP14 P/N: HSS106639 and HSS106640). RNA species were incubated with Lipofectamine RNAiMax reagent (Invitrogen, Carlsbad, CA, USA) and Opti-MEM (Invitrogen) prior to plating. Subsequently, the complex was added to suspended $1 \times 10^{5}$ cells per-well plated in 6-well plates. Mock-transfected cells were transfected only with Lipofectamine RNAiMax reagent and Opti-MEM at plating. The transfection procedures were as previously described $(15,16)$.
Reverse transcription-quantitative PCR (RT-qPCR). Total RNA was isolated using Isogen (Nippon Gene, Tokyo, Japan) according to the manufacturer's instructions. The integrity of the RNA was checked using an RNA 6000 Nano assay kit and a 2100 Bioanalyzer (Agilent Technologies, Santa Clara, CA, USA).

The procedure for PCR quantification was as previously described $(12,15,16)$. In brief, we first synthesized cDNA from total RNA of each sample using the TaqMan Reverse Transcription kit (P/N N8080234 and 4366596, Applied Biosystems). Subsequently, we evaluated the expression of the gene by TaqMan Real-Time PCR Assays. TaqMan probes and primers for MMP14 (P/N: Hs1037003_g1; Applied Biosystems) were assay-on-demand gene expression products. Stem-loop RT-PCR for miR-150-5p (assay ID: 000473; Applied Biosystems) was used. Human GUSB (P/N: Hs99999908_m1; Applied Biosystems) and RNU48 (assay ID: 001006; Applied Biosystems) were used as normalized controls. All reactions were performed in triplicate and the $\Delta \Delta \mathrm{Ct}$ method was employed to calculate the fold change.

Cell proliferation, migration and invasion assays. To investigate the functional significance of $m i R-150-5 p$ or MMP14 silencing by siRNA knockdown, we performed cell proliferation, migration and invasion assays using the SK-MES-1 and EBC-1 cells.

The cells were transfected with $10 \mathrm{nM}$ miRNA or siRNA by reverse transfection and plated in 96-well plates at $5 \times 10^{4}$ cells per well. After $72 \mathrm{~h}$, cell proliferation was determined by XTT assay using Cell Proliferation kit (Biological Industries, Kibbutz Beit Haemek, Israel).

Cell migration activity was evaluated by wound healing assay. The cells were seeded in 6 -well plates at $1 \times 10^{5}$ cells per well. At $48 \mathrm{~h}$ after transfection, the cell monolayer was scraped using a P-200 micropipette tip. The initial gap length and residual gap length $24 \mathrm{~h}$ after wounding were calculated from photomicrographs.

Cell invasion assay was carried out using modified Boyden chambers, consisting Transwell pre-coated Matrigel membrane filter inserts with $8 \mu \mathrm{m}$ pores in 24-well tissue culture plates (BD Biosciences, Bedford, MA, USA). At $48 \mathrm{~h}$ after transfection, the cells were planted in the inserts at $1 \times 10^{5}$ per well. At $72 \mathrm{~h}$ after transfection, the cells invaded to the lower side were fixed and stained with Diff-Quick (Sysmex Corp., Kobe, Japan). The number of cells invaded to the lower surface was determined microscopically by counting 8 areas of constant size per well. All experiments were performed in triplicate. The procedures of these functional assays were as previously described $(15,16)$.

Western blot analysis. At $72 \mathrm{~h}$ after transfection, protein lysates $(50 \mu \mathrm{g})$ were separated on NuPAGE on $4-12 \%$ Bis-Tris gels (Invitrogen) and transferred onto polyvinylidene fluoride membranes (GE Healthcare Japan, Tokyo, Japan). Immunoblotting was performed with monoclonal MMP14 antibody (1:2,000 dilution) (ab51074; Abcam, Cambridge, UK). GAPDH antibody (1:10,000 dilution) (ab8245; Abcam) was used as an internal control. The membranes were washed and then incubated with an anti-rabbit-IgG, HRP-linked antibody (\#7074; Cell Signaling Technology, Danvers, MA, USA). Complexes were visualized with Clarity Western ECL Substrate (Bio-Rad, Hercules, CA, USA). The procedures have been described in our previous studies $(15,16)$. 
Table I. Characteristics of lung cancer and non-cancerous cases.

A, Characteristics of the lung cancer cases

\begin{tabular}{lcr}
\hline Lung cancer patients & $\mathrm{n}$ & $(\%)$ \\
\hline Total number & 33 & \\
Median age (range, years) & $70(55-88)$ & \\
Sex & & \\
Male & 31 & 93.9 \\
Female & 2 & 6.1 \\
Pathological stage & & \\
IA & 5 & 15.2 \\
IB & 9 & 27.3 \\
IIA & 4 & 12.1 \\
IIB & 6 & 18.2 \\
IIIA & 8 & 24.2 \\
IIIB & 1 & 3.0 \\
\hline B, Characteristics of the non-cancerous cases & \\
\hline Non-cancerous tissues & $\mathrm{n}$ & \\
\hline Total number & 24 & \\
Median age (range, years) & $69(50-88)$ & \\
Sex & & \\
Male & 24 & \\
Female & 0 & \\
\hline
\end{tabular}

Identification of miR-150-5p target oncogenic genes in LUSQ cells. Specific genes regulated by $m i R-150-5 p$ were identified by a combination of in silico and comprehensive gene expression analyses. Our target search strategies were described as previously $(15,16)$. First, we selected putative $m i R-150-5 p$ target genes using the TargetScan 7.1 database (http://www. targetscan.org/vert_71/). We then performed comprehensive gene analysis of downregulated genes in $m i R-150-5 p$ transfected EBC-1 cells and upregulated genes in NSCLC from GEO database. The microarray data were deposited into GEO (http://www.ncbi.nlm.nih.gov/geo/), with the Accession number: GSE82108. Upregulated genes in NSCLC clinical specimens were obtained from the GEO database (Accession number: GSE19188).

Plasmid construction and dual-luciferase reporter assays. The wild-type or deletion-type sequences of the 3'-untranslated region (UTR) of MMP14 in $m i R-150-5 p$ target sites were inserted in the psiCHECK-2 vector (C8021; Promega, Madison, WI, USA). We used 3 sequences that were putative $m i R-150-5 p$ target sites of MMP14 by the TargetScan database (position 567-573: UUGGGAG; position 804-810: UGGGAGA and position 1381-1388: UUGGGAGA). The procedure for dual luciferase reporter assays was as previously described $(15,16)$. The synthesized DNA was cloned into the psiCHECK-2 vector. EBC-1 cells were transfected with the vector, miRNAs and Lipofectamine 2000 in Opti-MEM (both from Invitrogen). The activities of Firefly and Renilla luciferases in cell lysates
Table II. Immunohistochemistry status and characteristics of the lung cancer and non-cancerous cases.

A, Immunohistochemical status and characteristics of the LUSQ cases

Patient Grade T N M Pathological Immunohistochemical no. stage staining intensity

\begin{tabular}{rcccccc}
\hline 1 & 1 & 3 & 1 & 0 & IIIA & $(+)$ \\
2 & 1 & 3 & 0 & 0 & IIIA & $(++)$ \\
3 & 2 & 2 & 1 & 0 & II & $(+++)$ \\
4 & 2 & 3 & 0 & 0 & IIIA & $(++)$ \\
5 & 1 & 2 & 0 & 0 & I & $(++)$ \\
6 & 1 & 2 & 1 & 0 & II & $(+++)$ \\
7 & 1 & 3 & 1 & 0 & IIIA & $(++)$ \\
8 & 1 & 2 & 0 & 0 & I & $(++)$ \\
9 & 1 & 2 & 1 & 0 & II & $(++)$ \\
10 & 1 & 2 & 0 & 0 & I & $(+++)$ \\
11 & 2 & 2 & 2 & 0 & IIIA & $(++)$ \\
12 & 2 & 2 & 0 & 0 & I & $(+++)$ \\
13 & 2 & 1 & 0 & 0 & I & $(+++)$ \\
14 & 2 & 1 & 0 & 0 & I & $(+++)$ \\
15 & 2 & 2 & 1 & 0 & II & $(++)$ \\
16 & 2 & 3 & 1 & 0 & IIIA & $(+++)$ \\
17 & 2 & 2 & 0 & 0 & I & $(++)$ \\
18 & 2 & 2 & 1 & 0 & II & $(++)$ \\
19 & 2 & 3 & 2 & 0 & IIIA & $(+++)$ \\
20 & 2 & 2 & 0 & 0 & I & $(++)$ \\
\hline & & & & & &
\end{tabular}

$\mathrm{B}$, Immunohistochemical status of non-cancerous cases

Patient no. Immunohistochemical staining intensity

\begin{tabular}{rc}
\hline 91 & $(+)$ \\
92 & $(+)$ \\
93 & $(+)$ \\
94 & $(-)$ \\
95 & $(+)$ \\
96 & $(+)$ \\
97 & $(-)$ \\
98 & $(++)$ \\
99 & $(+)$ \\
100 & $(+)$ \\
\hline
\end{tabular}

were determined with a dual-luciferase assay system (E1910; Promega). Normalized data were calculated as the quotient of Renilla/Firefly luciferase activities.

Immunohistochemistry staining and scoring. A tissue microarray containing a total of 30 lung samples, 20 LUSQ specimens and 10 normal lung samples was obtained from US Biomax (Derwood, MD, USA; Cat. no. BC04002). The patient characteristics for the tissue microarray are shown in Table II. The TNM classification of cancer tissues was according to the 7 th edition of the American Joint Committee on Cancer (22). 
A

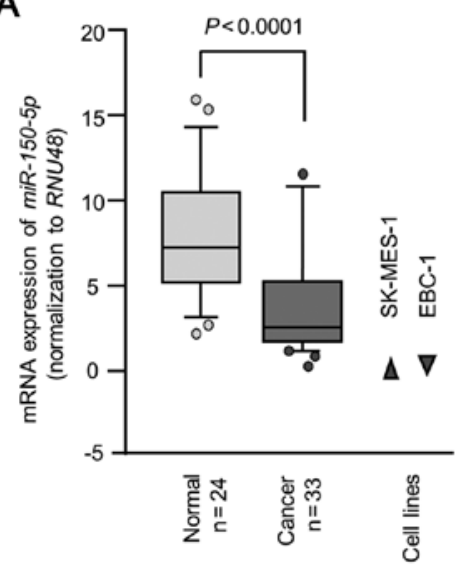

B

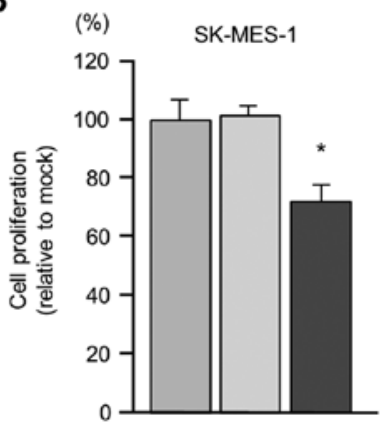

C
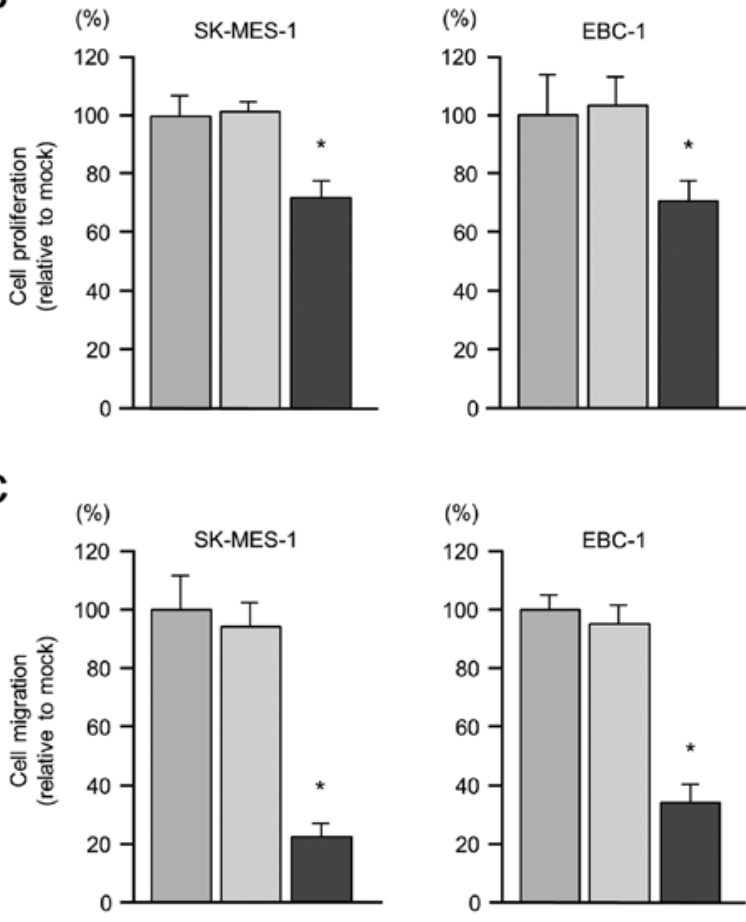

D

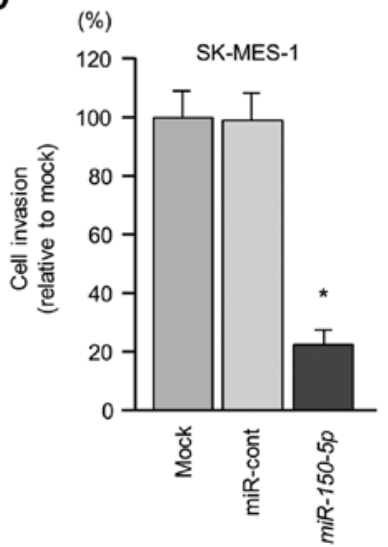

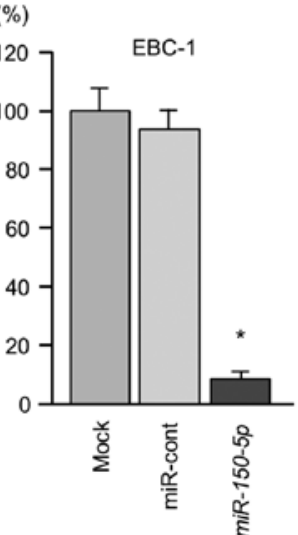

Figure 1. Expression levels of $m i R-150-5 p$ in clinical specimens and cell lines and functional assays of $m i R-150-5 p$ in LUSQ cells. (A) Expression levels of $m i R-150-5 p$ in LUSQ clinical specimens and cell lines. $R N U 48$ was used as an internal control. (B) Cell proliferation was determined by XTT assay $72 \mathrm{~h}$ after transfection with miR-150-5p; ${ }^{*} \mathrm{P}<0.0001$. (C) Cell movement was assessed by migration assays $72 \mathrm{~h}$ after transfection with $m i R-150-5 p$; ${ }^{*} \mathrm{P}<0.0001$. (D) Characterization of cell invasive capacity $72 \mathrm{~h}$ after transfection with $m i R-150-5 p$; ${ }^{*} \mathrm{P}<0.0001$.

We confirmed the expression status of MMP14 in the LUSQ clinical specimens using immunohistochemical staining. The procedure for immunohistochemistry was as previously described $(16,23,24)$. The tissue sections were incubated with the primary rabbit monoclonal antibody against MMP14 (1:5,000 dilution; ab51074; Abcam). The slide was treated with biotinylated goat anti-rabbit antibodies. Diaminobenzidine hydrogen peroxidase was the chromogen and counterstaining was done with $0.5 \%$ hematoxylin. Each tissues sample was scored on the basis of the intensity and area of staining. The procedure for score for staining tissues was as previously described (25).

Statistical analysis. Relationships between two or three variables and numerical values were analyzed using Mann-Whitney $\mathrm{U}$ tests or Bonferroni-adjusted Mann-Whitney U tests. Expert
StatView software (version 5.0; SAS Institute Inc., Cary, NC, USA) was used for these analyses. Statistical analysis was carried out as previously described $(19,23)$.

\section{Results}

Expression levels of miR-150-5p in LUSQ clinical specimens and cell lines. The expression levels of miR-150-5p were significantly decreased in the cancer tissues compared with non-cancerous tissues $(\mathrm{P}<0.0001$; Fig. $1 \mathrm{~A})$. In addition, the expression levels of $m i R-150-5 p$ in the cancer cell lines, SK-MES-1 and EBC-1, were markedly downregulated (Fig. 1A).

Effects of the ectopic overexpression of miR-150-5p on cell proliferation, migration and invasion in LUSQ cell lines. 
Table III. Putative target genes regulated by miR-150-5p in LUSQ cells.

\begin{tabular}{llcccc}
\hline Gene symbol & \multicolumn{1}{c}{ Gene name } & Conserved & $\begin{array}{c}\text { Poorly } \\
\text { conserved }\end{array}$ & $\begin{array}{c}\text { GEO82108 } \\
\log _{2} \text { ratio }\end{array}$ & $\begin{array}{c}\text { GEO19188 } \\
\text { Fold change }\end{array}$ \\
\hline MMP14 & Matrix metallopeptidase 14 (membrane-inserted) & 1 & 2 & -1.11 & 1.872 \\
$C P D$ & Carboxypeptidase D & 1 & 0 & -1.07 & 1.071 \\
LRRC58 & Leucine rich repeat containing 58 & 1 & 6 & -1.19 & 0.733 \\
$C D C 73$ & Cell division cycle 73 & 1 & 2 & -2.16 & 0.605 \\
ENSA & Endosulfine alpha & 1 & 5 & -1.79 & 0.501 \\
DSEL & Dermatan sulfate epimerase-like & 1 & 0 & -1.17 & 0.487 \\
$C S N K 1 A 1$ & Casein kinase 1, alpha 1 & 1 & 1 & -1.13 & 0.292 \\
$C H D 2$ & Chromodomain helicase DNA binding protein 2 & 1 & 2 & -2.14 & 0.260 \\
$C A P Z B$ & Capping protein (actin filament) muscle Z-line, beta & 1 & 4 & -1.18 & 0.201 \\
\hline
\end{tabular}

\section{Selection strategy for identification of miR-150-5p regulated genes}

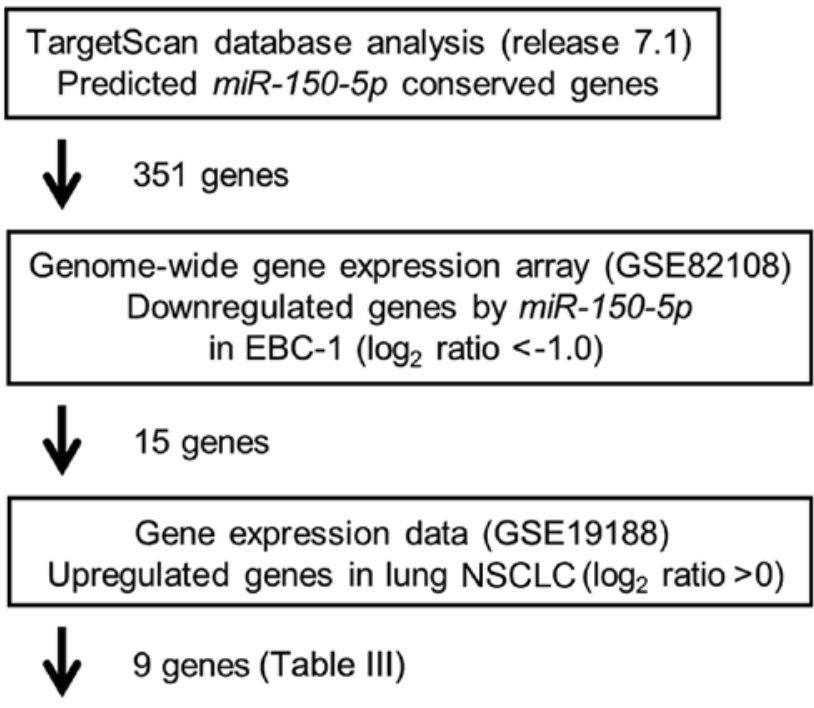

Figure 2. Flow chart depicting the strategy for identification of $m i R-150-5 p$ target genes. Combined in silico database searching and comprehensive gene expression analysis using $m i R-150-5 p$ transfectants of EBC-1 were applied to identify putative $m i R-150-5 p$ target genes. A total of 9 genes were identified as candidate targets of $m i R-150-5 p$ regulation.

To validate the antitumor effects of $m i R-150-5 p$, we carried out gain-of-function assays by transfecting miRNA into two LUSQ cell lines (SK-MES-1 and EBC-1). Cell proliferation was significantly inhibited in the cells transfected with the mature miR-150-5p in comparison with the mock (transfection reagent only)- or miR-control-transfected cells (Fig. 1B). Furthermore, cell migration and invasion activities were markedly reduced in the cells transfected with the miR-150-5p expression plasmid compared to the mock- or miR-controltransfected cells (Fig. 1C and D).

Identification of putative targets of miR-150-5p regulation in LUSQ cells. Our strategy for the selection of miR-150-5p target oncogenic genes is shown in Fig. 2. First, we selected putative $m i R-150-5 p$ target genes using the TargetScan 7.1 database and identified 351 genes. We then performed comprehensive gene expression analysis using miR-150-5p transfectants of EBC-1 cells, with negative control miRNA transfectants serving as controls (Accession number: GSE 82108). In this assessment, 15 genes were commonly downregulated $\left(\log _{2}\right.$ ratio $\left.<-1.0\right)$. The gene set was then analyzed with a publicly available gene expression data set in GEO (Accession number: GSE 19188) and genes upregulated in LUSQ were selected (fold change $>0$ ). A total of 9 genes were identified as candidate targets of $m i R-150-5 p$ regulation (Table III).

Among these candidate genes, we focused on MMP14 as the aberrant expression of the matrix metalloproteinase family enhances cancer cell migration and invasion (26). The ectopic overexpression of miR-150-5p significantly inhibited cancer cell migration and invasion in the LUSQ cells (Fig. 1C and D).

Direct regulation of MMP14 by miR-150-5p in LUSQ cells. We investigated whether transfection of the LUSQ cell lines with the miR-150-5p expression plasmid would reduce the expression of $M M P 14 / M M P 14$. The mRNA expression levels of MMP14 were decreased by transfection with the $m i R-150-5 p$ expression plasmid compared with the mock- or miR-control-transfected cells (Fig. 3A). Furthermore, the protein expression levels of MMP14 were also decreased by the overexpression of $m i R-150-5 p$ compared with the mock- or miR-control-transfected cells (Fig. 3B).

We also performed luciferase reporter assays with a vector that included the 3'-UTR of MMP14 to confirm that miR-150-5p directly regulated MMP14 in a sequence-dependent manner. We used vectors encoding the partial wild-type or deletiontype sequences of the 3'-UTR of the MMP14 with miR-150-5p target sites. Three binding sites for $m i R-150-5 p$ in the 3'-UTR of MMP14 (positions 567-573, 804-810 and 1381-1388) were predicted by the TargetScan Human database (Fig. 3C). We observed that the luminescence intensities of the proteins coded by vectors carrying the wild-type sequences (positions 804-810 and 1381-1388) were significantly reduced by co-transfection with miR-150-5p (Fig. 3C). By contrast, transfection with the deletion-type vector blocked the reduction of luminescence intensities (Fig. 3C). These findings indicated that $m i R-150-5 p$ directly bound to specific two sites in the 3'-UTR of MMP14. 
A

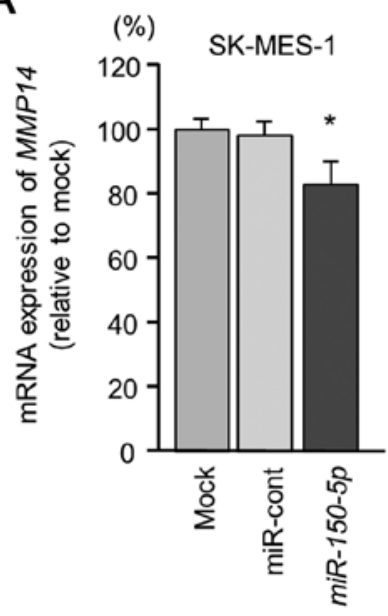

(\%)

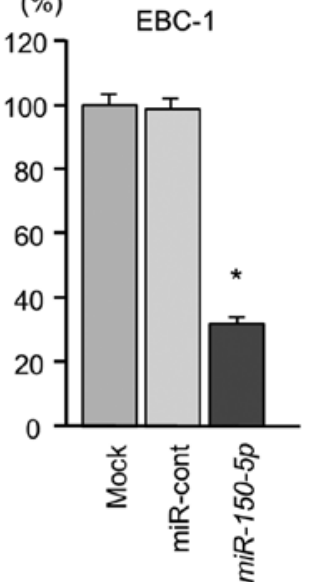

B

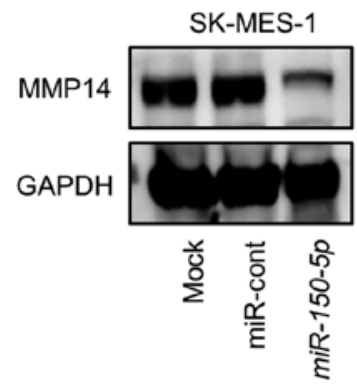

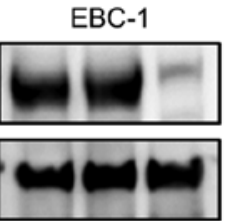

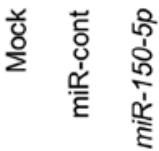

C

Position 567-573 of MMP14 3' UTR

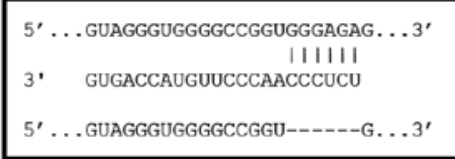

Position 804-810 of MMP14 3' UTR
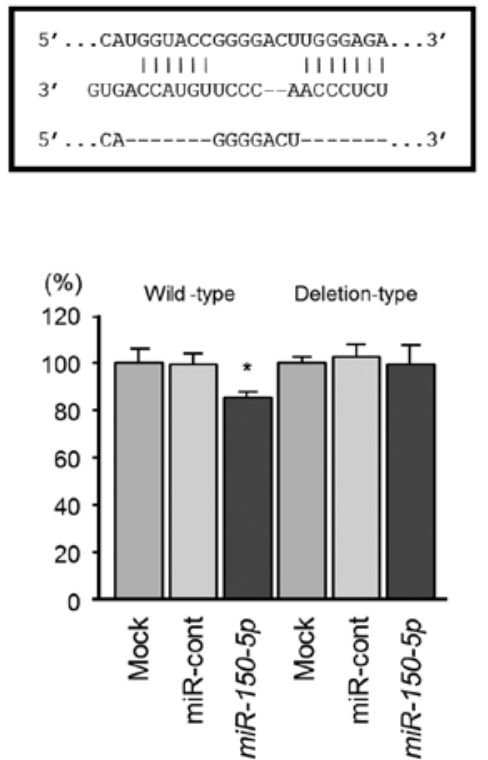

Position 1381-1388 of MMP14 3' UTR
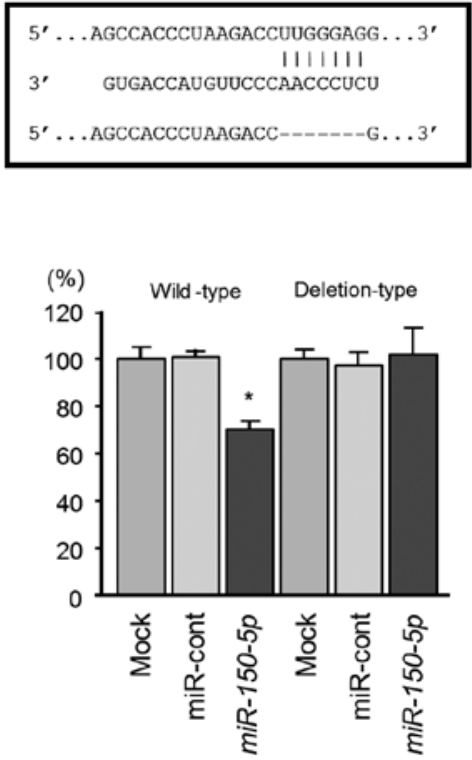

Figure 3. Direct regulation of $M M P 14$ by $m i R-150-5 p$ in LUSQ cells. (A) Expression levels of $M M P 14$ mRNAs $72 \mathrm{~h}$ after transfection of cell lines with $10 \mathrm{nM}$ $m i R-150-5 p$. GUSB was used as an internal control; ${ }^{*} \mathrm{P}<0.0001$. (B) Protein expression of MMP14 at $72 \mathrm{~h}$ after transfection with $m i R-150-5 p$. GAPDH was used as a loading control. (C) miR-150-5p binding sites in the 3'-UTR of MMP14 mRNA. Dual luciferase reporter assays using vectors encoding putative miR-150-5p target sites of the MMP14 3'-UTR (positions 567-573, 804-810 and 1381-1388) for wild-type and deletion type. Normalized data were calculated as ratios of Renilla/Firefly luciferase activities; ${ }^{*} \mathrm{P}<0.0001$.

Effects of knockdown of MMP14 on the proliferation, migration and invasion of LUSQ cell lines. Loss-of-function assays using siRNA were performed to examine the function of $M M P 14$ in LUSQ cell lines (SK-MES-1 and EBC-1). The mRNA and protein expression levels of MMP14 were decreased by transfection with si-MMP14 in the LUSQ cell lines (Fig. 4A and B).

We then investigated the effects of MMP14 knockdown on the proliferation, migration, and invasion of LUSQ cell lines. Cancer cell proliferation was significantly reduced in the si-MMP14-transfected cells (Fig. 4C). In addition, the migration and invasion activities were significantly attenuated in the si-MMP14-transfected cells (Fig. 4D and E).

Expression of MMP14 in LUSQ clinical specimens. We examined the protein expression levels of MMP14 in LUSQ clinical specimens by immunostaining. We confirmed the overexpression of MMP14 in LUSQ lesions compared with that in normal tissues (Fig. 5).

Identification of MMP14-regulated genes in LUSQ cells. To investigate downstream genes regulated by $M M P 14$, we performed genome-wide gene expression analysis using si-MMP14 in EBC-1 cells. A total of 92 genes were identified as MMP14-regulated genes (Table IV).

\section{Discussion}

Recently, several treatment options have been approved for post-first-line therapy for LUSQ, such as chemotherapy with or without an angiogenesis inhibitor (27), or immunotherapy (4). However, treatment outcomes do not appear to have improved. Therefore, clinicians need new treatment options in their 
A

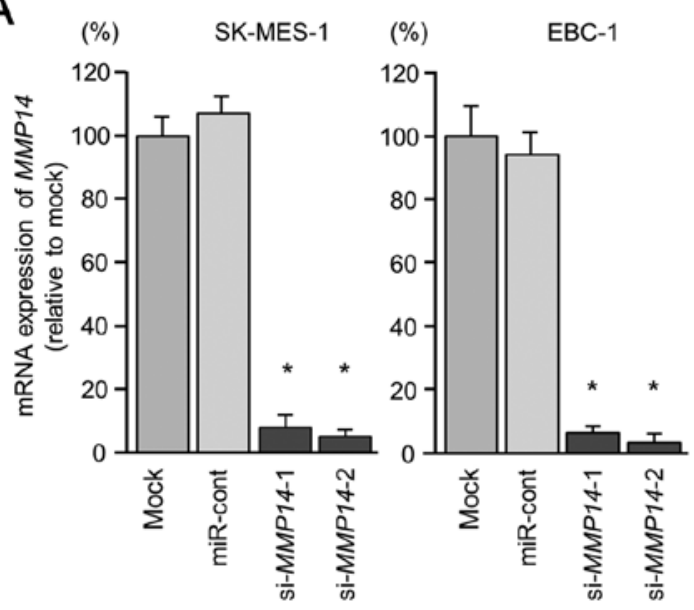

B

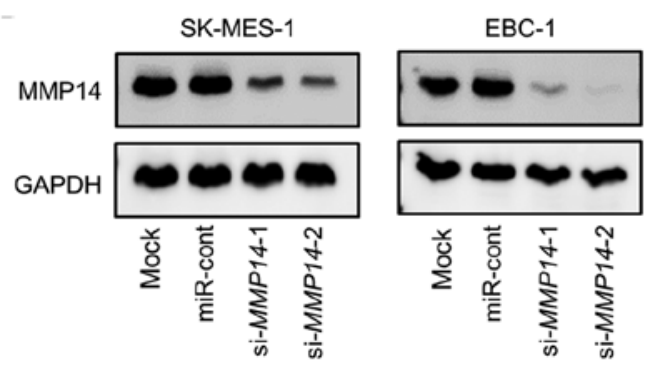

C

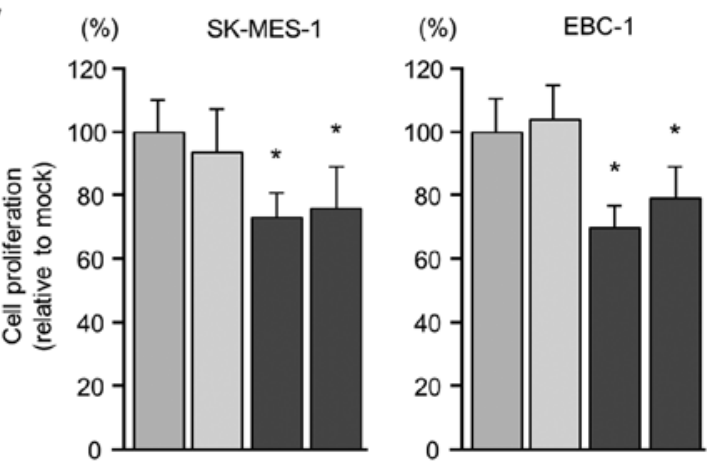

D
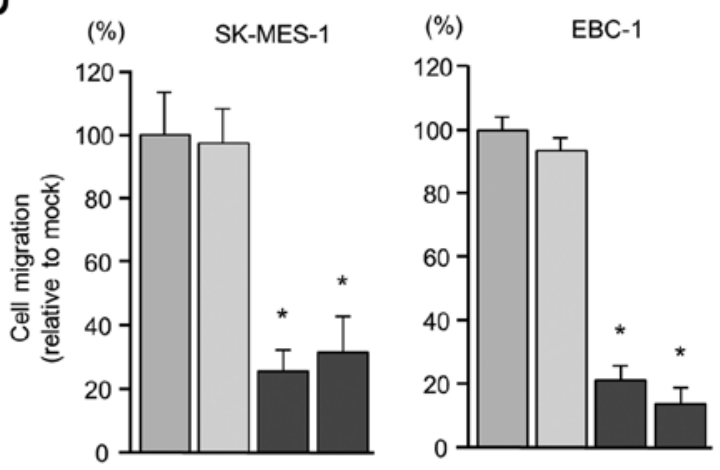

$E$

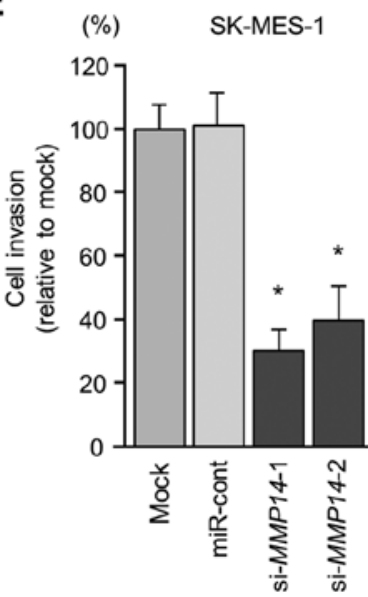

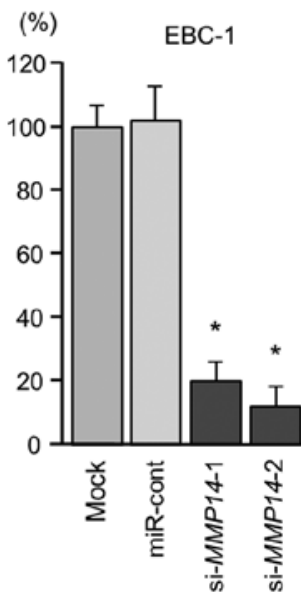

Figure 4. Knockdown of MMP14 by siRNA transfection and the response of LUSQ cells. (A) MMP14 mRNA expression at $72 \mathrm{~h}$ after transfection of $10 \mathrm{nM}$ siRNA into LUSQ cells. GUSB was used as an internal control; "P<0.0001. (B) MMP14 protein expression $72 \mathrm{~h}$ after transfection with siRNA. GAPDH was used as a loading control. (C) Cell proliferation was determined by XTT assay at $72 \mathrm{~h}$ after transfection with siRNA; "P<0.0001. (D) Cell movement was assessed by migration assay $72 \mathrm{~h}$ after transfection with siRNA; ${ }^{\circ} \mathrm{P}<0.0001$. (E) Characterization of invasion at $72 \mathrm{~h}$ after transfection with siRNA; $\mathrm{P}<0.0001$.

approach to LUSQ. Presumably, they should be based on the latest molecular analyses of the pathology of this disease.

In this study, we demonstrated that the restoration of $m i R-150-5 p$ significantly attenuated with cancer cell aggressiveness, suggesting that this miRNA possesses antitumor activity in LUSQ cells. It has been demonstrated that $m i R-150-5 p$ has multiple functions, possessing antitumor activity or oncogenic functions (28). The overexpression of $m i R-150-5 p$ has been reported in several types of cancer $(29,30)$. In contrast to the overexpression of $m i R-150-5 p$ in cancer cells, the antitumor roles of $m i R-150-5 p$ have been reported in several types of cancer through its targeting of oncogenic genes $(19,31,32)$.
Previous studies showed that contradiction resulted as to the expression pattern of $m i R-150-5 p$ in lung cancer (28). Our preliminary data demonstrated that the expression levels of $m i R-150-5 p$ were reduced in lung adenocarcinoma clinical specimens (data not shown). One such study showed that $m i R-150-5 p$ expression was significantly reduced in HNSCC tissues and had antitumor roles. A low expression of $m i R-150-5 p$ has been shown to be significantly associated with a poor prognosis of patients with HNSCC (19). Moreover, integrin subunit alpha 3 (ITGA3), integrin subunit alpha 6 (ITGA6) and tenascin $\mathrm{C}(T N C)$ have been identified as oncogenes in HNSCC that were downregulated by $m i R-150-5 p$ (19). 
Table IV. Downstream genes regulated by MMP14 in LUSQ cells.

Expression $\log _{2}$ ratio

Gene symbol

Gene name

si-MMP14-1 si-MMP14-2 Average

\begin{tabular}{|c|c|c|c|c|}
\hline MMP14 & Matrix metallopeptidase 14 (membrane-inserted) & -4.19 & -3.72 & -3.96 \\
\hline$L M N B 1$ & Lamin B1 & -3.70 & -2.97 & -3.34 \\
\hline TMEM192 & Transmembrane protein 192 & -2.61 & -3.48 & -3.05 \\
\hline MKI67 & Marker of proliferation $\mathrm{Ki}-67$ & -2.17 & -3.85 & -3.01 \\
\hline ENPP1 & Ectonucleotide pyrophosphatase/phosphodiesterase 1 & -2.77 & -3.11 & -2.94 \\
\hline$L P L$ & Lipoprotein lipase & -2.81 & -3.05 & -2.93 \\
\hline SLC7A11-AS1 & SLC7A11 antisense RNA 1 & -3.90 & -1.90 & -2.90 \\
\hline$C D R T 1$ & CMT1A duplicated region transcript 1 & -3.92 & -1.77 & -2.85 \\
\hline FAM129A & Family with sequence similarity 129, member A & -3.68 & -1.97 & -2.83 \\
\hline$B Z W 1$ & Basic leucine zipper and $\mathrm{W} 2$ domains 1 & -3.08 & -2.58 & -2.83 \\
\hline LYRM1 & LYR motif containing 1 & -2.63 & -2.90 & -2.76 \\
\hline CHRNA5 & Cholinergic receptor, nicotinic, alpha 5 (neuronal) & -3.31 & -2.20 & -2.75 \\
\hline MARCH5 & Membrane-associated ring finger (C3HC4) 5 & -2.23 & -3.23 & -2.73 \\
\hline$D E P D C 1$ & DEP domain containing 1 & -3.34 & -2.06 & -2.70 \\
\hline$C B X 3$ & Chromobox homolog 3 & -3.06 & -2.27 & -2.66 \\
\hline ANKRD22 & Ankyrin repeat domain 22 & -1.50 & -3.76 & -2.63 \\
\hline$J K A M P$ & JNK1/MAPK8-associated membrane protein & -1.66 & -3.37 & -2.51 \\
\hline ANTXR1 & Anthrax toxin receptor 1 & -2.39 & -2.59 & -2.49 \\
\hline$S M A D 1-A S 1$ & SMAD1 antisense RNA 1 & -2.29 & -2.69 & -2.49 \\
\hline$A T P 5 E$ & $\begin{array}{l}A T P \text { synthase, } \mathrm{H}+\text { transporting, mitochondrial F1 complex, } \\
\text { epsilon subunit }\end{array}$ & -2.31 & -2.64 & -2.47 \\
\hline TOMM20 & Translocase of outer mitochondrial membrane 20 homolog (yeast) & -2.40 & -2.41 & -2.40 \\
\hline$D E F B 4 A$ & Defensin, beta $4 \mathrm{~A}$ & -2.62 & -2.12 & -2.37 \\
\hline$A L D H 7 A 1$ & Aldehyde dehydrogenase 7 family, member A1 & -2.48 & -2.25 & -2.37 \\
\hline$O S B P L 8$ & Oxysterol binding protein-like 8 & -2.70 & -1.99 & -2.34 \\
\hline GLYCTK & Glycerate kinase & -2.58 & -2.08 & -2.33 \\
\hline$S L C 16 A 1$ & Solute carrier family 16 (monocarboxylate transporter), member 1 & -2.82 & -1.82 & -2.32 \\
\hline C5 & Complement component 5 & -2.18 & -2.42 & -2.30 \\
\hline$A S N S$ & Asparagine synthetase (glutamine-hydrolyzing) & -3.09 & -1.50 & -2.29 \\
\hline POLE2 & Polymerase (DNA directed), epsilon 2 , accessory subunit & -1.53 & -3.05 & -2.29 \\
\hline SASS6 & Spindle assembly 6 homolog (C. elegans) & -1.94 & -2.62 & -2.28 \\
\hline SMARCA2 & $\begin{array}{l}\text { SWI/SNF related, matrix associated, actin dependent regulator of } \\
\text { chromatin, subfamily a, member } 2\end{array}$ & -1.81 & -2.68 & -2.24 \\
\hline FANCD2 & Fanconi anemia, complementation group D2 & -2.19 & -2.27 & -2.23 \\
\hline TMEM154 & Transmembrane protein 154 & -2.69 & -1.77 & -2.23 \\
\hline ARHGAP9 & Rho GTPase activating protein 9 & -2.73 & -1.73 & -2.23 \\
\hline SPATA5 & Spermatogenesis associated 5 & -2.64 & -1.68 & -2.16 \\
\hline ARHGAP11A & Rho GTPase activating protein $11 \mathrm{~A}$ & -1.71 & -2.59 & -2.15 \\
\hline OSBPL8 & Oxysterol binding protein-like 8 & -2.12 & -2.16 & -2.14 \\
\hline SUV39H2 & Suppressor of variegation 3-9 homolog 2 (Drosophila) & -1.77 & -2.50 & -2.13 \\
\hline ACTL8 & Actin-like 8 & -2.36 & -1.85 & -2.10 \\
\hline ESCO2 & Establishment of sister chromatid cohesion $\mathrm{N}$-acetyltransferase 2 & -2.52 & -1.68 & -2.10 \\
\hline$R A B 1 A$ & RAB1A, member RAS oncogene family & -2.07 & -2.13 & -2.10 \\
\hline FBXO4 & F-box protein 4 & -1.76 & -2.42 & -2.09 \\
\hline МАРК6 & Mitogen-activated protein kinase 6 & -2.32 & -1.86 & -2.09 \\
\hline RNF 180 & Ring finger protein 180 & -1.91 & -2.25 & -2.08 \\
\hline DKFZP434I0714 & Uncharacterized protein DKFZP434I0714 & -1.77 & -2.38 & -2.08 \\
\hline
\end{tabular}


Table IV. Continued

Expression $\log _{2}$ ratio

Gene symbol

Gene name

si-MMP14-1 si-MMP14-2 Average

MTBP

AIF $1 L$

MDM2 binding protein

$M O B 3 B$

Allograft inflammatory factor 1-like

$C G G B P 1$

MOB kinase activator 3B

HIST1H2AI

CGG triplet repeat binding protein 1

FKBP5

Histone cluster 1, H2ai

NUDT21

FK506 binding protein 5

NEIL3

ATG4C

Nudix (nucleoside diphosphate linked moiety X)-type motif 21

ECELI

Nei endonuclease VIII-like 3 (E. coli)

KIF 11

Autophagy-related 4C, cysteine peptidase

TCF19 Transcription factor 19

Endothelin converting enzyme-like 1

ZNF681 Zinc finger protein 681

RRM2 Ribonucleotide reductase M2

PLAC8L1

PLAC8-like 1

$I L 1 B$

DIS3L

$$
\text { Interleukin 1, beta }
$$

CKAP2L

DIS3 like exosome 3'-5' exoribonuclease

RRN3

TMEM180

Cytoskeleton associated protein 2-like

HS2ST1

RRN3 RNA polymerase I transcription factor homolog (S. cerevisiae)

ZNF414 Zinc finger protein 414

Transmembrane protein 180

TMEM194B Transmembrane protein 194B

STXBP5L Syntaxin binding protein 5-like

CENPI Centromere protein I

ERCC6L excision repair cross-complementation group 6-like

$S P C 24$

KRTAP10-3

SPC24, NDC80 kinetochore complex component

ID2-ASI

GATA2-AS1

Keratin associated protein 10-3

$F B F 1$

$M E D 1$

ID2 antisense RNA 1 (head to head)

PLCL2

GATA2 antisense RNA 1

CDKN3

CSF3

PLAA

MCM6

TRIM14

TUBA3FP

Fas (TNFRSF6) binding factor 1

Mediator complex subunit 1

OVOS2

NUCKS1

HOOK 1

ZBTB33

GALNT4

RRM1

MDMI

Phospholipase C-like 2

Cyclin-dependent kinase inhibitor 3

Colony stimulating factor 3 (granulocyte)

Phospholipase A2-activating protein

Minichromosome maintenance complex component 6

Tripartite motif containing 14

Tubulin, alpha $3 \mathrm{f}$, pseudogene

Ovostatin 2

FAM72D
Nuclear casein kinase and cyclin-dependent kinase substrate 1

Hook microtubule-tethering protein 1

Zinc finger and BTB domain containing 33

Polypeptide $\mathrm{N}$-acetylgalactosaminyltransferase 4

Ribonucleotide reductase M1

Mdm1 nuclear protein homolog (mouse)

Family with sequence similarity 72 , member D

$-1.93$

$-2.44$

$-1.57$

$-1.75$

$-2.46$

$-1.79$

$-1.54$

$-2.02$

$-1.64$

$-1.89$

$-1.55$

$-1.64$

$-2.03$

$-1.66$

$-1.55$

$-1.69$

$-1.81$

$-1.66$

$-1.54$

$-2.12$

$-1.57$

$-1.74$

$-1.69$

$-1.92$

$-1.98$

$-1.60$

$-1.79$

$-1.85$

$-1.55$

$-2.03$

$-1.55$

$-1.64$

$-2.01$

$-1.56$

$-1.55$

$-1.53$

$-1.81$

$-1.64$

$-1.66$

$-1.76$

$-1.58$

$-1.62$

$-1.72$

$-1.70$

$-1.61$

$-1.69$

$-1.51$

$-2.21$

$-2.07$

$-2.06$

$-2.05$

$-2.04$

$-2.04$

$-2.03$

$-2.00$

$-1.96$

$-1.95$

$-1.92$

$-1.90$

$-1.90$

$-1.89$

$-1.88$

$-1.88$

$-1.87$

$-1.85$

$-1.84$

$-1.84$

$-1.84$

$-1.84$

$-1.82$

$-1.82$

$-1.82$

$-1.81$

$-1.81$

$-1.81$

$-1.80$

$-1.78$

$-1.78$

$-1.78$

$-1.78$

$-1.77$

$-1.74$

$-1.73$

$-1.70$

$-1.70$

$-1.69$

$-1.68$

$-1.67$

$-1.67$

$-1.64$

$-1.61$

$-1.61$

$-1.61$

$-1.61$

$-1.59$ 
A

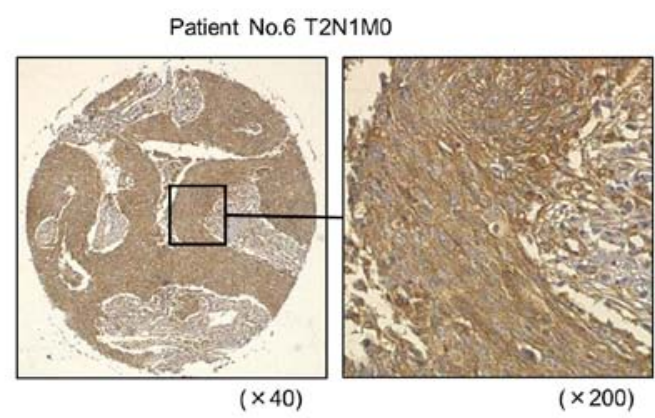

B

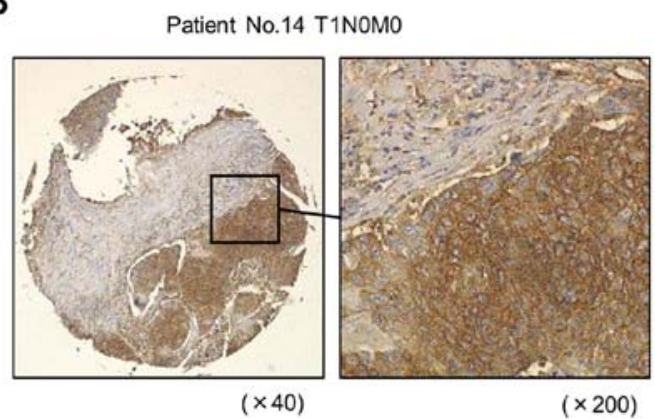

C

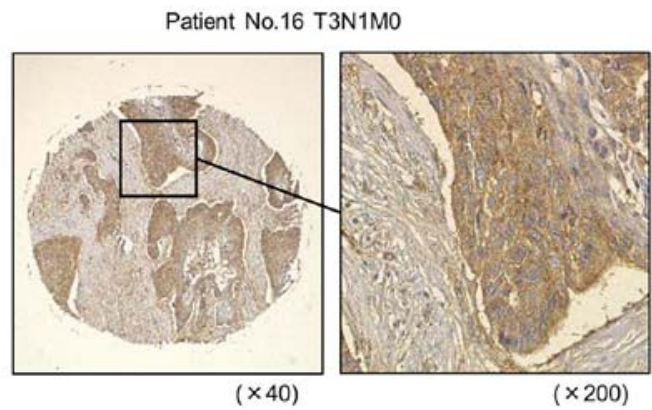

D

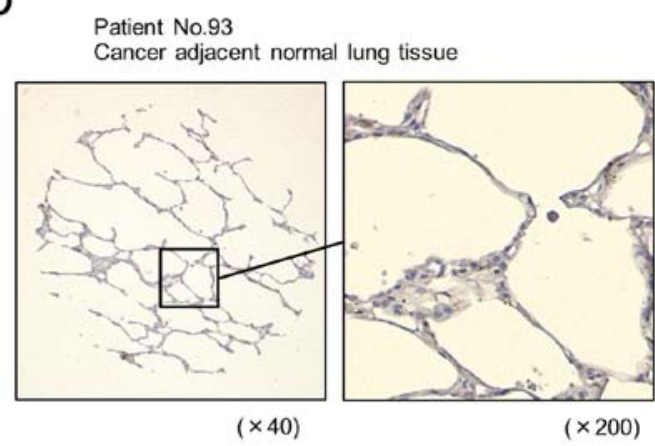

E

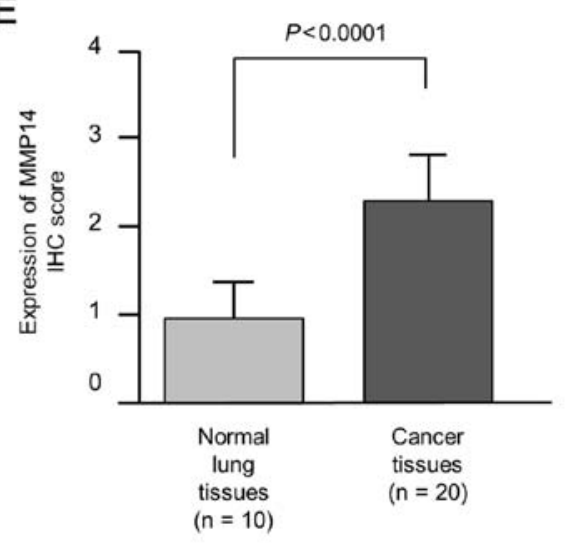

Figure 5. Expression of MMP14 in clinical LUSQ specimens using a tissue microarray. (A-C) Immunohistochemical (IHC) staining of MMP14 in LUSQ specimens. The overexpression of MMP14 was observed in cancer lesions. (D) Expression of MMP14 was negative in normal lung tissue. (E) Comparison of IHC staining of MMP14 in LUSQ tissues using IHC scores. MMP14 expression was significantly higher in cancer tissues than in normal lung tissues.

Previous studies have shown that the aberrant expression of integrin family genes and the activation of integrin-mediated oncogenic signaling promotes cancer cell metastasis and the epithelial-mesenchymal transition (EMT) phenotype $(33,34)$. Other studies have demonstrated that SPOCKI is directly regulated by $m i R-150-5 p$ in prostate cancer and esophageal squamous cell carcinoma $(31,32)$. The aberrant expression of SPOCK1 has been observed in several types of cancer and has been shown to play pivotal roles in cancer cell progression, metastasis and drug resistance $(35,36)$. Of note, the ectopic expression of SPOCK1 induces EMT in lung cancer (37). These findings suggest that the downregulation of $m i R-150-5 p$ induces several cancer-promoting genes and that its expression is deeply involved in cancer pathogenesis.

In this study, to identify oncogenic genes targeted by $m i R-150-5 p$, we applied gene expression analysis and in silico database searches. A total of 9 genes (MMP14, CPD, LRRC58, $C D C 73, E N S A, D S E L, C S N K 1 A 1, C H D 2$ and $C A P Z B)$ were identified as putative targets of $m i R-150-5 p$ regulation in LUSQ cells. Among these, we focused on MMP14 as the matrix metalloproteinase family contributes to cancer cell migration and invasion. Our luciferase reporter assay revealed that MMP14 was directly regulated by $m i R-150-5 p$ in LUSQ cells. The overexpression of MMP14 was observed in LUSQ clinical specimens and the knockdown of MMP14 by siRNA significantly interfered in vitro with cancer cell malignancies. These findings indicate that MMP14 acts as an oncogene regulated by the antitumor $m i R-150-5 p$ in LUSQ cells.

MMP14 belongs to the membrane-type matrix metalloprotease (MT-MMP) family that includes pivotal regulators of cell invasion, growth and survival in normal cells (26). The upregulation of MMP14 has been observed in many types of cancer, and the overexpression of MMP14 has been shown to correlate with a poor prognosis in patients with NSCLC, renal cell carcinoma and breast cancer (38-40). Activated MMP14 cleaves pro-MMP2 and pro-MMP13 and the activated form of MMP2 and MMP13 are involved in cancer pathogenesis (26). A major substrate of MMP14 is type I collagen in ECM components. MMP14 is localized to the leading edge of invadopodia in migrating cells, achieving spatially coordinated matrix 
degradation to support invasion (41). MMP14 influences cancer cells and cancer niches (ECM and fibroblast cells). MMP14 is mediated through membrane proteins, e.g., receptor tyrosine kinases (RTK) and integrins, and these events promote cancer cell aggressiveness $(42,43)$. For instance, he interaction of MMP14 and CD44 induces the phosphorylation of the EGF receptor and enhances downstream activation of the MAPK and PI3K signaling pathways $(44,45)$.

Proteolytic enzymes, MMPs or MT-MMPs are tightly controlled by tissue inhibitors of metalloproteases (TIMPs) (26). The expression and activation of MMPs and TIMPs are important to biological processes and essential for tissue homeostasis. Dysregulated MMPs and TIMPs have been implicated in cancer cell progression and metastasis (46). Recent studies have indicated that several downregulated miRNAs caused the aberrant expression of MMP14 in cancer cells $(47,48)$. Our recent studies showed the antitumor functions of $m i R-375$ and $m i R-139-5 p /-3 p$ that targeted $M M P 13$ and $M M P 11$, respectively $(49,50)$. These MMPs were overexpressed in cancer specimens, and the restoration of these miRNAs or knockdown of MMP13 or MMP11 inhibited cancer cell migration and invasion $(49,50)$. The identification of antitumor miRNAs that regulate novel LUSQ networks may lead to a better understanding of the aggressiveness of this disease.

Taken together, this study demonstrates $m i R-150-5 p$ acts as an antitumor miRNA by targeting MMP14 in LUSQ cells. The overexpression of MMP14 may be enhanced in lung cancer oncogenesis. The exploration of antitumor miRNA-mediated regulatory networks may lead to the development of novel treatment strategies for this disease.

\section{Acknowledgements}

This study was supported by the Japan Society for the Promotion of Science (JSPS) Grants-in-Aid for Scientific Research (KAKENHI), 17K16893, 15K10801, 16K19458, and $17 \mathrm{~K} 09660$.

\section{Competing interests}

The authors declare that they have no competing interests.

\section{References}

1. Cheng TY, Cramb SM, Baade PD, Youlden DR, Nwogu C and Reid ME: The international epidemiology of lung cancer: Latest trends, disparities, and tumor characteristics. J Thorac Oncol 11: 1653-1671, 2016.

2. Travis WD: Pathology of lung cancer. Clin Chest Med 32: 669-692, 2011.

3. Reck M,Heigener DF, Mok T, Soria JC and Rabe KF: Management of non-small-cell lung cancer: Recent developments. Lancet 382: 709-719, 2013.

4. Reck M, Rodríguez-Abreu D, Robinson AG, Hui R, Csőszi T, Fülöp A, Gottfried M, Peled N, Tafreshi A, Cuffe S, et al; KEYNOTE-024 Investigators: Pembrolizumab versus chemotherapy for PD-L1-positive non-small-cell lung cancer. N Engl J Med 375: 1823-1833, 2016.

5. Sandler AB, Schiller JH, Gray R, Dimery I, Brahmer J, Samant M, Wang LI and Johnson DH: Retrospective evaluation of the clinical and radiographic risk factors associated with severe pulmonary hemorrhage in first-line advanced, unresectable nonsmall-cell lung cancer treated with Carboplatin and Paclitaxel plus bevacizumab. J Clin Oncol 27: 1405-1412, 2009.
6. Scagliotti GV, Parikh P, von Pawel J, Biesma B, Vansteenkiste J, Manegold C, Serwatowski P, Gatzemeier U, Digumarti R, Zukin M, et al: Phase III study comparing cisplatin plus gemcitabine with cisplatin plus pemetrexed in chemotherapynaive patients with advanced-stage non-small-cell lung cancer. J Clin Oncol 26: 3543-3551, 2008.

7. Paz-Ares L, Tan EH, O'Byrne K, Zhang L, Hirsh V, Boyer M, Yang JC, Mok T, Lee KH, Lu S, et al: Afatinib versus gefitinib in patients with EGFR mutation-positive advanced non-smallcell lung cancer: Overall survival data from the phase $\mathrm{IIb}$ LUX-Lung 7 trial. Ann Oncol 28: 270-277, 2017.

8. Djebali S, Davis CA, Merkel A, Dobin A, Lassmann T, Mortazavi A, Tanzer A, Lagarde J, Lin W, Schlesinger F, et al: Landscape of transcription in human cells. Nature 489: 101-108, 2012.

9. Beermann J, Piccoli MT, Viereck $\mathbf{J}$ and Thum T: Non-coding RNAs in development and disease: Background, mechanisms, and therapeutic approaches. Physiol Rev 96: 1297-1325, 2016.

10. Bartel DP: MicroRNAs: Target recognition and regulatory functions. Cell 136: 215-233, 2009.

11. Wiemer EA: The role of microRNAs in cancer: No small matter. Eur J Cancer 43: 1529-1544, 2007.

12. Mataki H, Enokida H, Chiyomaru T, Mizuno K, Matsushita R, Goto Y, Nishikawa R, Higashimoto I, Samukawa T, Nakagawa M, et al: Downregulation of the microRNA-1/133a cluster enhances cancer cell migration and invasion in lung-squamous cell carcinoma via regulation of Coronin1C. J Hum Genet 60: 53-61, 2015.

13. Kamikawaji K, Seki N, Watanabe M, Mataki H, Kumamoto T, Takagi K, Mizuno K and Inoue H: Regulation of LOXL2 and SERPINH1 by antitumor microRNA-29a in lung cancer with idiopathic pulmonary fibrosis. J Hum Genet 61: 985-993, 2016.

14. Mizuno K, Seki N, Mataki H, Matsushita R, Kamikawaji K, Kumamoto T, Takagi K, Goto Y, Nishikawa R, Kato M, et al: Tumor-suppressive microRNA-29 family inhibits cancer cell migration and invasion directly targeting LOXL2 in lung squamous cell carcinoma. Int J Oncol 48: 450-460, 2016.

15. Mataki H, Seki N, Mizuno K, Nohata N, Kamikawaji K, Kumamoto T, Koshizuka K, Goto Y and Inoue H: Dual-strand tumor-suppressor microRNA-145 (miR-145-5p and miR-145-3p) coordinately targeted MTDH in lung squamous cell carcinoma. Oncotarget 7: 72084-72098, 2016.

16. Mataki H, Seki N, Chiyomaru T, Enokida H, Goto Y, Kumamoto T, Machida K, Mizuno K, Nakagawa M and Inoue H: Tumor-suppressive microRNA-206 as a dual inhibitor of MET and EGFR oncogenic signaling in lung squamous cell carcinoma. Int J Oncol 46: 1039-1050, 2015.

17. Fukumoto I, Kikkawa N, Matsushita R, Kato M, Kurozumi A, Nishikawa R, Goto Y, Koshizuka K, Hanazawa T, Enokida H, et al: Tumor-suppressive microRNAs (miR-26a/b, miR-29a/b/c and miR-218) concertedly suppressed metastasis-promoting LOXL2 in head and neck squamous cell carcinoma. J Hum Genet 61: 109-118, 2016.

18. Kurozumi A, Kato M, Goto Y, Matsushita R, Nishikawa R, Okato A, Fukumoto I, Ichikawa T and Seki N: Regulation of the collagen cross-linking enzymes LOXL2 and PLOD2 by tumor-suppressive microRNA-26a/b in renal cell carcinoma. Int J Oncol 48: 1837-1846, 2016.

19. Koshizuka K, Nohata N, Hanazawa T, Kikkawa N, Arai T, Okato A, Fukumoto I, Katada K, Okamoto Y and Seki N: Deep sequencing-based microRNA expression signatures in head and neck squamous cell carcinoma: Dual strands of pre-miR-150 as antitumor miRNAs. Oncotarget 8: 30288-30304, 2017.

20. Goto Y, Kurozumi A, Arai T, Nohata N, Kojima S, Okato A, Kato M, Yamazaki K, Ishida Y, Naya Y, et al: Impact of novel miR-145-3p regulatory networks on survival in patients with castration-resistant prostate cancer. Br J Cancer 117: 409-420, 2017.

21. Itesako T, Seki N, Yoshino H, Chiyomaru T, Yamasaki T, HidakaåH, Yonezawa T, Nohata N, Kinoshita T, Nakagawa M, et al: The microRNA expression signature of bladder cancer by deep sequencing: The functional significance of the miR-195/497 cluster. PLoS One 9: e84311, 2014.

22. Mirsadraee S, Oswal D, Alizadeh Y, Caulo A and van Beek E Jr: The 7th lung cancer TNM classification and staging system: Review of the changes and implications. World J Radiol 4: 128-134, 2012.

23. Koshizuka K, Hanazawa T, Fukumoto I, Kikkawa N, Matsushita R, Mataki H, Mizuno K, Okamoto Y and Seki N: Dual-receptor (EGFR and c-MET) inhibition by tumorsuppressive miR-1 and miR-206 in head and neck squamous cell carcinoma. J Hum Genet 62: 113-121, 2017. 
24. Okato A, Goto Y, Kurozumi A, Kato M, Kojima S, Matsushita R, Yonemori M, Miyamoto K, Ichikawa T and Seki N: Direct regulation of LAMP1 by tumor-suppressive microRNA-320a in prostate cancer. Int J Oncol 49: 111-122, 2016.

25. Kojima S, Chiyomaru T, Kawakami K, Yoshino H, Enokida H, Nohata N, Fuse M, Ichikawa T, Naya Y, Nakagawa M, et al: Tumour suppressors miR-1 and miR-133a target the oncogenic function of purine nucleoside phosphorylase (PNP) in prostate cancer. Br J Cancer 106: 405-413, 2012.

26. Turunen SP, Tatti-Bugaeva $\mathrm{O}$ and Lehti K: Membrane-type matrix metalloproteases as diverse effectors of cancer progression. Biochim Biophys Acta 1864 (11 Pt A): 1974-1988, 2017.

27. Maione P, Sgambato A, Casaluce F, Sacco PC, Santabarbara G, Rossi A and Gridelli C: The role of the antiangiogenetic ramucirumab in the treatment of advanced non small cell lung cancer. Curr Med Chem 24: 3-13, 2017.

28. Wang F, Ren X and Zhang X: Role of microRNA-150 in solid tumors. Oncol Lett 10: 11-16, 2015.

29. Wu Q, Jin H, Yang Z, Luo G, Lu Y, Li K, Ren G, Su T, Pan Y, Feng B, et al: miR-150 promotes gastric cancer proliferation by negatively regulating the pro-apoptotic gene EGR2. Biochem Biophys Res Commun 392: 340-345, 2010.

30. Huang S, Chen Y, Wu W, Ouyang N, Chen J, Li H, Liu X, Su F, Lin L and Yao Y: miR-150 promotes human breast cancer growth and malignant behavior by targeting the pro-apoptotic purinergic P2X7 receptor. PLoS One 8: e80707, 2013.

31. Okato A, Arai T, Kojima S, Koshizuka K, Osako Y, Idichi T, Kurozumi A, Goto Y, Kato M, Naya Y, et al: Dual strands of pre-miR-150 (miR-150-5p and miR-150-3p) act as antitumor miRNAs targeting SPOCK1 in naïve and castration-resistant prostate cancer. Int J Oncol 51: 245-256, 2017.

32. Osako Y, Seki N, Koshizuka K, Okato A, Idichi T, Arai T, Omoto I, Sasaki K, Uchikado Y, Kita Y, et al: Regulation of SPOCK1 by dual strands of pre-miR-150 inhibit cancer cell migration and invasion in esophageal squamous cell carcinoma. J Hum Genet 62: 935-944, 2017.

33. Desgrosellier JS and Cheresh DA: Integrins in cancer: Biological implications and therapeutic opportunities. Nat Rev Cancer 10: 9-22, 2010

34. Gilcrease MZ: Integrin signaling in epithelial cells. Cancer Lett 247: 1-25, 2007.

35. Shu YJ, Weng H, Ye YY, Hu YP, Bao RF, Cao Y, Wang XA, Zhang F, Xiang SS, Li HF, et al: SPOCK1 as a potential cancer prognostic marker promotes the proliferation and metastasis of gallbladder cancer cells by activating the PI3K/AKT pathway. Mol Cancer 14: 12, 2015.

36. Kim HP, Han SW, Song SH, Jeong EG, Lee MY, Hwang D, Im SA, Bang YJ and Kim TY: Testican-1-mediated epithelialmesenchymal transition signaling confers acquired resistance to lapatinib in HER2-positive gastric cancer. Oncogene 33 3334-3341, 2014

37. Miao L, Wang Y, Xia H, Yao C, Cai H and Song Y: SPOCK1 is a novel transforming growth factor- $\beta$ target gene that regulates lung cancer cell epithelial-mesenchymal transition. Biochem Biophys Res Commun 440: 792-797, 2013.
38. Wang YZ, Wu KP, Wu AB, Yang ZC, Li JM, Mo YL, Xu M, Wu B and Yang ZX: MMP-14 overexpression correlates with poor prognosis in non-small cell lung cancer. Tumour Biol 35: 9815-9821, 2014

39. Lu H, Hu L, Yu L, Wang X, Urvalek AM, Li T, Shen C, Mukherjee D, Lahiri SK, Wason MS, et al: KLF8 and FAK cooperatively enrich the active MMP14 on the cell surface required for the metastatic progression of breast cancer. Oncogene 33: 2909-2917, 2014

40. Hagemann T, Gunawan B, Schulz M, Füzesi L and Binder C: mRNA expression of matrix metalloproteases and their inhibitors differs in subtypes of renal cell carcinomas. Eur J Cancer 37: 1839-1846, 2001

41. Gawden-Bone C, Zhou Z, King E, Prescott A, Watts C and Lucocq J: Dendritic cell podosomes are protrusive and invade the extracellular matrix using metalloproteinase MMP-14. J Cell Sci 123: 1427-1437, 2010.

42. Gálvez BG, Matías-Román S, Yáñez-Mó M, Sánchez-Madrid F and Arroyo AG: ECM regulates MT1-MMP localization with beta1 or alphavbeta3 integrins at distinct cell compartments modulating its internalization and activity on human endothelial cells. J Cell Biol 159: 509-521, 2002.

43. Munshi HG and Stack MS: Reciprocal interactions between adhesion receptor signaling and MMP regulation. Cancer Metastasis Rev 25: 45-56, 2006.

44. Cho SH, Park YS, Kim HJ, Kim CH, Lim SW, Huh JW, Lee JH and Kim HR: CD44 enhances the epithelial-mesenchymal transition in association with colon cancer invasion. Int J Oncol 41: 211-218, 2012.

45. Zarrabi K, Dufour A, Li J, Kuscu C, Pulkoski-Gross A, Zhi J, $\mathrm{Hu}$ Y, Sampson NS, Zucker S and Cao J: Inhibition of matrix metalloproteinase 14 (MMP-14)-mediated cancer cell migration. J Biol Chem 286: 33167-33177, 2011

46. Hojilla CV, Mohammed FF and Khokha R: Matrix metalloproteinases and their tissue inhibitors direct cell fate during cancer development. Br J Cancer 89: 1817-1821, 2003.

47. Li Y, Kuscu C, Banach A, Zhang Q, Pulkoski-Gross A, Kim D, Liu J, Roth E, Li E, Shroyer KR, et al: miR-181a-5p inhibits cancer cell migration and angiogenesis via downregulation of matrix metalloproteinase-14. Cancer Res 75: 2674-2685, 2015.

48. Zuo QF, Cao LY, Yu T, Gong L, Wang LN, Zhao YL, Xiao B and Zou QM: MicroRNA-22 inhibits tumor growth and metastasis in gastric cancer by directly targeting MMP14 and Snail. Cell Death Dis 6: e2000, 2015.

49. Osako Y, Seki N, Kita Y, Yonemori K, Koshizuka K, Kurozumi A, Omoto I, Sasaki K, Uchikado Y, Kurahara H, et al: Regulation of MMP13 by antitumor microRNA-375 markedly inhibits cancer cell migration and invasion in esophageal squamous cell carcinoma. Int J Oncol 49: 2255-2264, 2016.

50. Yonemori M, Seki N, Yoshino H, Matsushita R, Miyamoto K, Nakagawa $M$ and Enokida H: Dual tumor-suppressors miR-139-5p and miR-139-3p targeting matrix metalloprotease 11 in bladder cancer. Cancer Sci 107: 1233-1242, 2016. 